\title{
METAMORPHISM AND IGNEOUS ACTION*
}

\author{
By Prof. H. H. READ, F.R.S., \\ Imperial College of Science and TeChNology, London
}

\begin{abstract}
[T $\mathrm{HE}$ consideration of the relation between metamorphism and igneous action, which forms the subject of Prof. H. H. Read's presidential address to Section C (Geology), falls into two parts. First, a brief historical summary of the peculiarly national contributions serves to display the wide divergences in opinion on this question. The views of the Rosenbusch school of pure thermal metamorphism are contrasted with the imbibition notions of the French, and the work of Becke of Vienna, the Swiss, Sederholm of Finland and the Americans is reviewed. The classic investigations of George Barrow on zones of progressive regional metamorphism in the Highlands north of Dundee and their causal relation to granitic injections are sympathetically summarized. In the second part of the address, a discussion is presented of the origin of regional metamorphism, that is, of the transformations which have affected large portions of the earth's crust.]
\end{abstract}

I first note the equivalence, according to Rosenbusch and others, of regional and dynamic meta. morphism. The forerunner of the term dynamic metamorphism was Lossen's dislocation-metamorphism, a simple expression denoting a trans. formation genetically connected with dislocations of the crust. Lossen's old term would cover a large class of phenomena, such as the dominantly mechanical breaking-down of rocks, cataclasis, mylonitization and the like, all connected with demonstrable dislocations. I propose to continue to use dislocation-metamorphism for this class of phenomena.

Rosenbusch, having replaced Lossen's excellent term by his dynamic metamorphism, proceeded to make this the equivalent of regional metamorphism, and to regard orogenic pressure as its cause. Backed by the authority of Rosenbusch, dynamic metamorphism became fashionable, the dynamic aspect overshadowed all others and mountain-building movements could do all things requisite and necessary. It must be remembered, however, that many of the French were frankly sceptical; nevertheless, the notion of a metamorphism on a regional scale "induced in rocks because of their deformation" remains still a leading principle in many schools of metamorphic geology.

* From the presidential address prepared for Section C (Geology) of the British Association.
On the other hand, the emergence of ideas on a static or load metamorphism of regional extent, in which orogenic pressure is not a causal condition, indicates that all is not well with the supposed equivalence of dynamic and regional metamorphisms. Before discussing static metamorphism itself, I deal with some of the diffeculties raised by this equivalence.

I mention certain facts commonly observed in regionally metamorphosed rocks but difficult to reconcile with the operation of pressures tangential to the earth's surface. One of the chief of these observations is the coincidence of schistosity and bedding. As metamorphic rocks showing this coincidence are often horizontal over great areas, the notion of static or load metamorphism has been put forward. But Daly has cited a score of regions where schistosity and bedding agree-in folded and horizontal rocks alike. These are the phenomena that Daly felt to be "truly inexplicable by pure dynamic metamorphism", an opinion with which I am in complete accord.

The preservation of original textures in rocks that have been completely recrystallized is a matter of common observation. There are innumerable examples of the preservation in regionally metamorphosed rocks of minute sedimentation-characters, such as graded bedding, current bedding, the interlamination of undisturbed, exceedingly thin, beds, and so forth-characters that should have been obliterated by the action of orogenic pressures. As an instance of how excellent this preservation may be, I may recall the successful use of current bedding and graded bedding in unravelling the stratigraphical sequence in the Grampian Highlands. An additional and telling example is the recognition of varved bedding in the metamorphic rocks of Finland and Canada. It seems to me that such details of original textures cannot possibly be preserved if the rocks in which they occur were metamorphosed "because of their deformation". I admit, of course, the operation of dynamic action in the production of various metamorphic rocks of low grade, but in these cases the original primary textures are completely obliterated. This obliteration in low-grade metamorphism and preservation in high grade meta. morphism of original textures shake my faith in the unity of the progressive series from the chlorite zone or epizone to zones of higher grade. 
Whilst stress is admittedly the dominant factor in the production of low-grade metamorphic rocks, there is agreement that its effect is small in the higher grades, where the products of regional and thermal metamorphisms converge, high temperatures being in control. There is no correspondence between the degree of deformation and the metamorphic grade, unless it be one of the greater the deformation the lower the grade. In this con. nexion, I may cite the failure of experimental work, like that of Larsen and Bridgman, to produce minerals characteristic of rocks supposedly formed by dynamic metamorphism. Stress, by itself, is not enough.

No one can dispute the observed fact that regionally metamorphosed rocks are often more or less violently folded. The inference so often made that the metamorphism and the folding are coeval is not, however, always justified. It seems to me clear that most fold-structures in regionally metamorphosed rocks ante-date the crystallization, this being post-tectonic in the terminology of Sander.

It will be realized, I trust, that there are many features of regional metamorphism that are incompatible with dynamic action. The recognition of this has led to the invocation of static or load metamorphism, and I examine the validity of this notion.

One of the especial difficulties that has to be faced by adrocates of a metamorphism due to the vertical pressure of the overlying beds is the existence of completely non-metamorphic rocks which have nevertheless been covered by an immense thickness of superincumbent strata.

This difficulty confronting static metamorphism has been tackled by Daly, who meets it by relaxing the rigidity of the doctrine of uniformitarianism. He admits that, compared with its proposed potency in Pre-Cambrian times, load-metamorphism must have been of relatively little importance in later geological eras. To account for this, he assumes that the earth's thermal gradient was stceper during the formation of the Pre-Cambrian so that regional metamorphism under a moderate corer was possible. I am not competent to discuss Daly's speculation, and $I$ have only to state that I feel that the proposal does not strengthen the case for regional static metamorphism.

The idea of a metamorphism controlled by load, as such, fails to meet many other observations. I have space here only to cite the occurrence, in the eastern United States, of highly metamorphosed stratigraphically younger beds resting naturally on lowly metamorphosed stratigraphically older beds; of high-grade sillimanite-zone rocks overlying lower-grade rocks as in Sutherland and Norway; of the passage, in Banffshire, from slates to metamorphosed rocks containing andalusite, garnet, cordierite, sillimanite and staurolite within a half-mile of coast-section; of a similar narrow restriction in the Barrovian zones as in Dutchess County, New York. Load, by itself, is not enough.

The literature of regional metamorphism abounds in references to the great depths within the crust at which such metamorphism takes place. These suggestions of great depths, however, carry no kind of conviction to my mind. On the contrary, I consider that high-grade regionally metamorphosed rocks must have been formed in many areas under relatively little cover. Daly was of this opinion, too, and he was influenced thereby in his idea that thermal conditions were different in Pre-Cambrian time from what they were in Palæozoic time. He pointed out that from Clarke's data it is possible to form a rough estimate of the total amount of rock eroded in geological time, and that only a small portion of this amount can be assigned to Pre-Cambrian time. Of this small portion, part is represented in the nonmetamorphic Pre-Cambrian sediments which lie unconformably on the metamorphosed basement. The several complexes of the basement were highly metamorphic before the denudations corresponding to the unconformities which separate them. From a consideration of these points, and of the great volume of Pre-Cambrian rocks, Daly concludes that the average cover on the complexes at the time of their metamorphism was much less than 5,000 metres in thickness. Barrell came to a similar conclusion by an argument based upon the amount of salt in the sea, and the erosion of the igneous rocks to give this. He decided that Pre-Cambrian erosion had removed a cover of less than a mile in thickness.

Though these arguments may not appear altogether sound to some, still I suspect that the notion of the great depths of regional metamor. phism flourishes because of the supposed necessity of carrying rocks down to be metamorphosed. I suggest that as an alternative we should consider the possibility of bringing the metamorphosing agents up.

I next discuss certain aspects of the zonal notion, especially in connexion with a depthcontrol.

I note the development of ideas on depth-zones and, in connexion with static and load meta. morphism, I direct attention to difficulties encountered in regarding grade of metamorphism as directly controlled by depth. Admittedly, metamorphism does often increase in grade with depth, but, as I have said in another place, I personally find no difficulty in envisaging a metamorphism which increases laterally or vertically; I consider depth, as such, not to be a factor in metamorphism, 
and that if we are to retain a zonal notion, then the idea of depth-control must be completely disregarded.

The relation between the large-scale tectonics and the metamorphic zones in the Highlands is a question which, in the present state of our knowledge, bristles with difficulties. The Cambridge School considers that the metamorphism is pretectonic, and that the metamorphic zones can be recumbently folded. On the other hand, Bailey and others regard the metamorphism as partly contemporaneous with the folding. For my part, I suggest that the metamorphism may be posttectonic. Both in the Highlands and elsewhere it seems to me that the isograde lines are independent of both stratigraphical and tectonic arrangements, and I prefer to relate regional metamorphism not to load, nor to deformation, nor to tectonic or any other depth.

I hare pointed out the destruction of sedi. mentary structures in low-grade metamorphism and their apparent perfect preservation in high. grade metamorphism. If these are valid observations, then it seems to me that the progressive series from slates to higher-grade rocks must break down, or, at least, that high-grade rocks were not necessarily at ono stage of their carcer in the condition represented by the lowest.grade rocks of the zonal series. Low-grade rocks may once have been high-grade, but the reverse is not necessarily true.

(T'o be continued.)

\title{
REACTIONS OF ACCLIMATIZATION AND OF NON-ADAPTATION
}

\author{
By Prof. M. Piery and Prof. J. Enselme, \\ Faculty of Medicine, Lyons
}

$\mathrm{U}^{\mathrm{P}}$ to the present time, physiologists have been especially concerned with the study of the acute effects of high altitudes or of acute mountain sickness. As a consequence of the work of Prof. Monge of Lima, who both discovered and studied chronic mountain sickness as manifested in human beings, we, in our turn, have investigated the experimental effects of high altitudes on animals. We believe that in this way we may be able to discover more about the mechanism of adaptation of organisms to altitude, and thus explain the pathogenesis of Carlos Monge's disease.

With this object in view, we studied the effects produced in various animals by a sojourn of six months in the laboratory of the Jungfraujoch, at an altitude of 3457 metres. We have already described elsewhere the technical methods and detailed observations which we have made in this experiment. Here, our object is to give expression to certain views which we hold relating to the adaptation of the animal organism to the lower atmospheric pressures of high altitudes.

The problem of the effects of altitude upon animal organisms gains considerably in depth and interest if, by exceeding certain limits which are usually accepted, we consider it from a more general point of view.

In order to do so, the following facts must first of all be taken into account:

(1) The problem constitutes a particular case of the much wider problem of adaptation in general; it is the case of adaptation to the lowering of atmospheric pressure.

(2) It consists of several biological stages which, like all adaptations, may be schematized as follows :

(a) A tissue forms the receptive element for the external infuence. Sometimes this is the skin, sometimes the digestive organs and, in this particular case, the lungs.

(b) The effects there are carried by a trans. mission system into the innermost tissues and set up a connexion between the receptive tissue and the whole of the organism. This transmission system consists of two physiological pathways, a neuro-vegetative action, adrenergic or cholinergic, or alternatively in the form of an action of a chemical messenger.

(c) A system of tissue reception which affects the various organs and those elements of intertissue synthesis; namely, the glands of internal secretion.

(d) A mechanism of genetic transmission, the reaction of the genital elements.

(3) Furthermore, in the case of each one of these components, the following must be distinguished:

(a) The modifications which appear as direct effects of the climatic change: as, for example, the modification of the tissues by chemical or mechanical influences.

(b) A number of reactions which are not so 